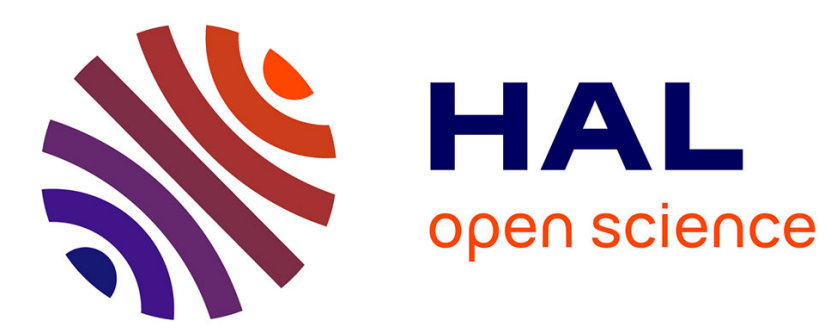

\title{
In search of tetraploid wheat accessions reduced in celiac disease-related gluten epitopes
}

Hetty van den Broeck, Hongbing Chen, Xavier Lacaze, Jean-Claude

Dusautoir, Gilissen Ludovicus, Marinus Smulders, Ingrid van Der Meer

\section{- To cite this version:}

Hetty van den Broeck, Hongbing Chen, Xavier Lacaze, Jean-Claude Dusautoir, Gilissen Ludovicus, et al.. In search of tetraploid wheat accessions reduced in celiac disease-related gluten epitopes. Molecular BioSystems, 2010, 6 (11), pp.2206-2213. 10.1039/c0mb00046a . hal-01190547

\section{HAL Id: hal-01190547 \\ https://hal.science/hal-01190547}

Submitted on 1 Sep 2015

HAL is a multi-disciplinary open access archive for the deposit and dissemination of scientific research documents, whether they are published or not. The documents may come from teaching and research institutions in France or abroad, or from public or private research centers.
L'archive ouverte pluridisciplinaire HAL, est destinée au dépôt et à la diffusion de documents scientifiques de niveau recherche, publiés ou non, émanant des établissements d'enseignement et de recherche français ou étrangers, des laboratoires publics ou privés. 


\title{
In search of tetraploid wheat accessions reduced in celiac disease-related gluten epitopes
}

\author{
Hetty van den Broeck, ${ }^{* a}$ Chen Hongbing, ${ }^{a}$ Xavier Lacaze, ${ }^{b}$ \\ Jean-Claude Dusautoir, ${ }^{b}$ Ludovicus Gilissen, ${ }^{a}$ Marinus Smulders ${ }^{a}$ and \\ Ingrid van der Meer ${ }^{a}$
}

Received 14th June 2010, Accepted 13th July 2010

DOI: $10.1039 / \mathrm{c0mb00046a}$

\begin{abstract}
Tetraploid wheat (durum wheat) is mainly used for the preparation of pasta. As a result of breeding, thousands of tetraploid wheat varieties exist, but also tetraploid landraces are still maintained and used for local food preparations. Gluten proteins present in wheat can induce celiac disease, a T-cell mediated auto-immune disorder, in genetically predisposed individuals after ingestion. Compared to hexaploid wheat, tetraploid wheat might be reduced in T-cell stimulatory epitopes that cause celiac disease because of the absence of the D-genome. We tested gluten protein extracts from 103 tetraploid wheat accessions (obtained from the Dutch CGN genebank and from the French INRA collection) including landraces, old, modern, and domesticated accessions of various tetraploid species and subspecies from many geographic origins. Those accessions were typed for their level of T-cell stimulatory epitopes by immunoblotting with monoclonal antibodies against the $\alpha$-gliadin epitopes Glia- $\alpha 9$ and Glia- $\alpha 20$. In the first selection, we found $8 \mathrm{CGN}$ and 6 INRA accessions with reduced epitope staining. Fourteen of the $57 \mathrm{CGN}$ accessions turned out to be mixed with hexaploid wheat, and 5 out of the 8 selected CGN accessions were mixtures of two or more different gluten protein chemotypes. Based on single seed analysis, lines from two CGN accessions and one INRA accession were obtained with significantly reduced levels of Glia- $\alpha 9$ and Glia- $\alpha 20$ epitopes. These lines will be further tested for industrial quality and may contribute to the development of safer foods for celiac patients.
\end{abstract}

\section{Introduction}

Tetraploid wheat is a so-called hard wheat and is generally used for the preparation of pasta, but in Mediterranean countries it is also used for the preparation of various types of breads. ${ }^{1}$ Tetraploid wheat has originated from a hybridization between Triticum urartu (an A-genome wheat species) and most likely Aegilops speltoides (a B-genome wheat species) resulting in a tetraploid species having the AB-genome. ${ }^{2-5}$ Tetraploid wheat domestication occurred in Southeastern Turkey. ${ }^{6-10}$ During thousands of years, cultivated tetraploid species spread throughout Europe and Asia because of human migration. Further cultivation and natural selection resulted in an enormous variation of tetraploid wheats, many of which have been collected in genebank collections as landraces. The features of the landraces depend on the local environmental conditions and on the local food traditions and food preparations. Many landraces are still maintained in some regions because the properties of their flour are considered important for traditional food applications. Landraces are adapted to local climatic conditions, cultural practices, and (partly) to disease and pests. ${ }^{7}$ A landrace may be a mixture of genotypes, which

\footnotetext{
${ }^{a}$ Wageningen UR, Plant Research International, P.O. Box 16, 6700 AA Wageningen, The Netherlands.

E-mail: hetty.busink@wur.nl; Fax: +31317418094;

Tel: + 31317480974

${ }^{b}$ INRA-UMR 1097-DIAPC, Domaine de Melgueil, 34130 Mauguio, France
}

evolved under the environmental conditions where they were grown because of natural selection and selection by the farmer. Tetraploid wheat can mix up with hexaploid bread wheat very easily under agricultural conditions and care should be taken if the tetraploid wheat should be maintained as a pure genotype. ${ }^{11}$ As a result, many commercial lots, currently sold as durum wheat, nearly always contain some hexaploid bread wheat.

The typical food-technological characteristics of wheat are related to the presence of gluten proteins. These proteins are water-insoluble, making them especially useful in a wide and still rapidly increasing variety of food applications. Gluten proteins are comprised of gliadins and glutenins, which are present in approximately equal amounts and form $80 \%$ of the total storage protein content in the wheat kernel. ${ }^{12}$ In tetraploid wheat, the genes encoding gliadins are located on the short arm of chromosomes 1A and 1B (Gli-1 loci) and on the short arm of chromosomes 6A and 6B (Gli-2 loci). The Gli-1 loci represent genes that are tightly linked and mainly encode the $\gamma$ - and $\omega$-gliadins. The Gli-2 loci represent tightly clustered genes encoding the $\alpha / \beta$ - and some $\gamma$-gliadins. ${ }^{13,14}$

Gluten proteins from wheat varieties used for preparation of pasta or bread (but also from rye and barley) can induce celiac disease (CD) in genetically susceptible individuals. ${ }^{15} \mathrm{CD}$ is characterized by an inflammation of the small intestine. The prevalence is about $1 \%$ in the Western (Caucasian) population. The vast majority $(\sim 95 \%)$ of this group is unaware of having $\mathrm{CD}$ because of large-scale underdiagnosis and wrong diagnosis. The incidence of CD appears to be increasing. ${ }^{16,17}$ The only 
cure today is a strict life-long gluten-free diet. However, it is difficult to avoid wheat gluten, because of its rapidly increasing application in an increasing number of food products. ${ }^{18}$ The starting point of our research is that any reduction in the total CD-stimulating gluten consumption will contribute to an overall reduction of the prevalence and symptom severity of CD.

Overall, tetraploid wheats contain less T-cell stimulatory $\alpha$-gliadin epitopes than hexaploid bread wheat because of the absence of the D-genome. ${ }^{19,20}$ The highly immunodominant T-cell stimulating $33-\mathrm{mer}^{21,22}$ is exclusively present in $\alpha$-gliadins encoded by the D-genome. In addition, the levels of T-cell stimulatory epitopes have been shown to vary among varieties (van den Broeck et al. in press). ${ }^{23-26}$ This opens possibilities to select for wheat varieties with significantly reduced $\alpha$-gliadin epitope levels, aiming at direct use or to apply in breeding programs directed towards large-scale reduction or even total elimination of CD-stimulating gluten-elements from wheat.

The aim of this study is to analyze, as a first step, the genetic diversity and heterogeneity regarding the presence of T-cell stimulatory epitopes of old and modern tetraploid wheat accessions collected from many geographic origins worldwide.

\section{Results}

The gluten protein extracts from all accessions were analyzed by immunoblotting using mAbs against the T-cell stimulatory epitopes Glia- $\alpha 9$ and Glia- $\alpha 20$ to identify the epitope sequence-containing gluten proteins (Fig. 1). In 14 out of 57 CGN accessions, an additional set of bands at $\sim 55-60 \mathrm{kDa}$ was observed reacting with both $\mathrm{mAbs}$ Glia- $\alpha 9$ and Glia- $\alpha 20$ (Fig. 1, proteins indicated by arrows). These proteins are also present in the hexaploid wheat variety Bovictus (Fig. 1, lane B). It was shown before ${ }^{27}$ that the genes encoding these two proteins, being $\omega$-gliadin/D-type LMW-GS, are located on the short arm of chromosome 1D in 'Chinese Spring' deletion lines. These proteins are also detected in diploid Triticum tauschii, containing the D-genome, and in the immunoblot analysis of CIMMYT synthetic hexaploid wheat lines, but are not stained in their tetraploid parent lines (results not shown). Therefore, the accessions showing the two chromosome 1D encoded proteins are, at least, admixed with hexaploid wheats. Single seeds from accession CGN08006 were used in cDNA sequencing as described by Salentijn et $a .^{20}$ and this confirmed its general tetraploidy by the absence of the D-genome sequences. Such admixtures were detected in wheat accessions originating from Ethiopia, Germany, USSR, Iran, France, and the USA (Fig. 1, lanes 18, 20, 23, 26, 28, 34, 35, 36, 45, 46, 51, 52, 55, and 56, Table 1). Two different seeds present in landrace accession CGN8360 (Fig. 1, lane 34) were confirmed in flow cytometric ploidy level determination to be hexaploid.

Five accessions originating from Egypt shared the same gluten protein pattern for $\mathrm{mAb}$ Glia- $\alpha 20$ but differed in one protein band for mAb Glia- $\alpha 9$ (Fig. 1, lanes 6, 7, 8, 11, and 12). These accessions probably share the same progenitors, or they may be independently propagated accessions in which small differences have been evolved e.g. because of mixtures with (related) genotypes. Accessions CGN16069 from Algeria and CGN16069 from Egypt seemed very similar to each other, as they showed the same patterns on immunoblots for both $\mathrm{mAbs}$ and are both mixed with hexaploid wheat (Fig. 1, lanes 55 and 56). For all other accessions, the gluten protein patterns on immunoblots were quite different, even if accessions originate from the same country.

In order to evaluate the presence and the level of T-cell stimulatory epitopes in tetraploid wheat accessions, eight accessions were selected that showed to contain a lower amount of T-cell stimulatory gluten proteins in the overall (seed mixture) protein pattern (Fig. 1, indicated with $\mathbf{\nabla}$ ). The seeds of accessions CGN08006, CGN07975, CGN08173, CGN08339, CGN08379, CGN08397, CGN08407, and CGN16074 were subsequently examined for the presence of different seed phenotypes. The phenotypes of the seeds of accession CGN08006 were diverse in seed color and shape and when the gluten proteins from nine phenotypically different seeds (A to I) were analyzed by immunoblotting, six different gluten protein chemotypes could be detected (Fig. 2). Accession CGN08006 is a landrace collected from Ethiopia which was originally classified as a hexaploid wheat. Another ten landraces from Ethiopia have been analyzed by immunoblotting and six of these were mixed with hexaploid wheat. In contrast, seeds from accessions CGN07975, CGN08339, and CGN08407 showed only one phenotype. Seeds from

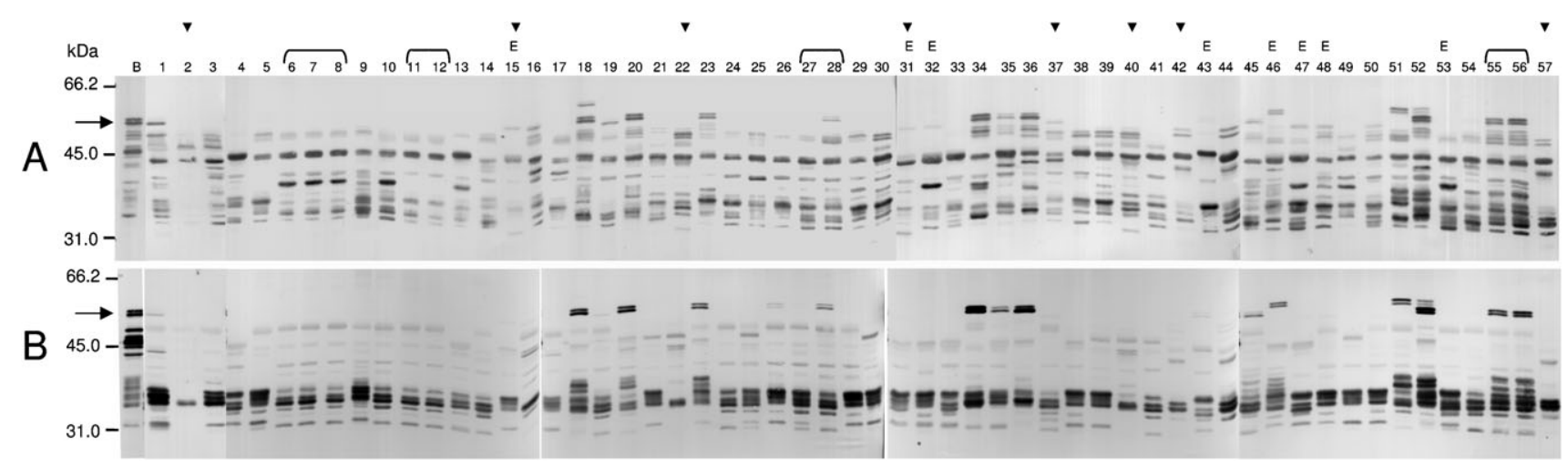

Fig. 1 Immunoblot analysis of gluten protein extracts from 57 tetraploid wheat accessions compared to the gluten protein extract of modern hexaploid variety Bovictus. (A) $\mathrm{mAb}$ Glia- $\alpha 9$, (B) mAb Glia- $\alpha 20$. Brackets group accessions with similar protein patterns. E is emmer wheat. $\boldsymbol{\nabla}$ indicates accessions selected for further analysis. All gluten proteins reacting to the mAbs are stained. 
Table 1 Details of tetraploid accessions obtained from CGN Wageningen, The Netherlands

\begin{tabular}{|c|c|c|c|c|c|c|c|c|}
\hline & Acc nr & Acc name & Species & Subspecies & Population type & Type & Collection date & Collection site \\
\hline 1 & CGN06223 & Lugaymi & T. aestivum & aestivum & $\mathrm{L}$ & & 1968 & Saudi Arabia \\
\hline 2 & CGN08006 & Dibillik Sinde & T. aestivum & aestivum & $\mathrm{L}$ & & 1972 & Ethiopia \\
\hline 3 & CGN12037 & Mate Sinde & T. aestivum & aestivum & $\mathrm{L}$ & & 1972 & Ethiopia \\
\hline 4 & CGN04221 & Black Persian & T. turgidum & carthlicum & $\mathrm{L}$ & Spring & 1962 & Iran \\
\hline 5 & CGN06550 & Dniepopetrovk & T. turgidum & durum & $\mathrm{B}$ & & 1965 & USSR \\
\hline 6 & CGN06551 & Gazal & T. turgidum & durum & & Spring & & Egypt \\
\hline 7 & CGN06552 & Gaza 2; Gaya W 277 & T. turgidum & durum & & Spring & 1937 & Egypt \\
\hline 8 & CGN06553 & Gaza 8; Gaza W 277 & T. turgidum & durum & & Spring & 1950 & Egypt \\
\hline 9 & CGN06555 & Kaza kylcyk & T. turgidum & durum & $\mathrm{L}$ & & & Azerbaijan \\
\hline 10 & CGN06567 & Hansia Broach & T. turgidum & durum & $\mathrm{L}$ & Spring & 1915 & India \\
\hline 11 & CGN06576 & Beladi & T. turgidum & durum & $\mathrm{L}$ & Spring & & Egypt \\
\hline 12 & CGN06578 & Beladi dakar & T. turgidum & durum & & & 1948 & Egypt \\
\hline 13 & CGN06582 & Gaurani & T. turgidum & durum & $\mathrm{L}$ & Spring & 1949 & India \\
\hline 14 & CGN06590 & Eretria & T. turgidum & durum & B & Spring & 1955 & Greece \\
\hline 15 & CGN07975 & Abessinischer Emmer & T. turgidum & dicoccon & & Spring & 1965 & Ethiopia \\
\hline 16 & CGN07989 & Beladi & T. turgidum & durum & $\mathrm{L}$ & Spring & 1939 & Egypt \\
\hline 17 & CGN07991 & St. 472 Ethiopia & T. turgidum & durum & $\mathrm{L}$ & Spring & 1950 & Ethiopia \\
\hline 18 & CGN08143 & Hongrie 2883 & T. turgidum & durum & $\mathrm{B}$ & Spring & 1965 & Portugal \\
\hline 19 & CGN08145 & Durazio Molar 918 & T. turgidum & durum & $\mathrm{B}$ & Spring & 1965 & Portugal \\
\hline 20 & CGN08146 & Candial & T. turgidum & durum & B & Spring & 1949 & Portugal \\
\hline 21 & CGN08154 & Akmolinka 5 & T. turgidum & durum & B & Spring & 1959 & USSR \\
\hline 22 & CGN08173 & Gharnovka & T. turgidum & durum & & & 1900 & USSR \\
\hline 23 & CGN08190 & Deves; Kamboyra & T. turgidum & durum & $\mathrm{L}$ & Spring & 1916 & Greece \\
\hline 24 & CGN08202 & Gandumi Andojird & T. turgidum & durum & & & 1940 & Iran \\
\hline 25 & CGN08232 & Psathas & T. turgidum & durum & $\mathrm{L}$ & Spring & 1957 & Cyprus \\
\hline 26 & CGN08235 & Hebda 3 & T. turgidum & durum & $\mathrm{B}$ & Spring & 1960 & Algeria \\
\hline 27 & CGN08239 & Etrusco & T. turgidum & durum & & Spring & 1961 & Italy \\
\hline 28 & CGN08240 & Capeiti & T. turgidum & durum & B & Spring & 1961 & Italy \\
\hline 29 & CGN08245 & Mokhtar II & T. turgidum & durum & $\mathrm{L}$ & Spring & & Egypt \\
\hline 30 & CGN08262 & Probstdorfer Pandur; Pandur & T. turgidum & durum & B & Spring & 1972 & Austria \\
\hline 31 & CGN08339 & Weisser Sommer & T. turgidum & dicoccon & $\mathrm{L}$ & Spring & $<1945$ & Germany \\
\hline 32 & CGN08341 & Yaroslav Spring Emmer & T. turgidum & dicoccon & $\bar{L}$ & Spring & & USSR \\
\hline 33 & CGN08357 & Diha & T. turgidum & carthlicum & $\mathrm{L}$ & Spring & 1964 & USSR \\
\hline 34 & CGN08360 & Diha Dzhavakhetskaja & T. turgidum & carthlicum & $\mathrm{L}$ & Spring & 1959 & USSR \\
\hline 35 & CGN08361 & & T. turgidum & carthlicum & $\mathrm{L}$ & Spring & 1958 & USSR \\
\hline 36 & CGN08367 & & T. turgidum & turgidum & $\mathrm{L}$ ? & Winter & & \\
\hline 37 & CGN08379 & Asa de Corvo 5279 & T. turgidum & turgidum & $\mathrm{L}$ ? & Spring & & Portugal \\
\hline 38 & CGN08390 & LHTAXO 549/65 & T. turgidum & polonicum & L? & Spring & 1965 & \\
\hline 39 & CGN08396 & Acme & T. turgidum & durum & B & Spring & 1963 & USA \\
\hline 40 & CGN08397 & Arnoutka & T. turgidum & durum & B & Spring & 1954 & USA \\
\hline 41 & CGN08398 & Golden Ball & T. turgidum & durum & $\mathrm{B}$ & Spring & 1961 & South Africa \\
\hline 42 & CGN08407 & & T. timopheevi & timopheevi & & Spring & & USSR \\
\hline 43 & CGN10468 & Vernal & T. turgidum & dicoccon & B & Spring & & USA \\
\hline 44 & CGN10495 & & T. timopheevi & timopheevi & $\mathrm{L}$ ? & Spring & 1964 & USSR \\
\hline 45 & CGN11494 & Brkulja & T. turgidum & durum & $\mathrm{L}$ & Winter & 1949 & Yugoslavia \\
\hline 46 & CGN12275 & Vernal Emmer & T. turgidum & dicoccon & $\mathrm{L}$ & Spring & 1962 & USA \\
\hline 47 & CGN12282 & & T. turgidum & dicoccon & & & 1952 & Iran \\
\hline 48 & CGN12283 & Polba 3 & T. turgidum & dicoccon & B & Spring & & USSR \\
\hline 49 & CGN12287 & Tripshiro & T. turgidum & durum & & Spring & 1921 & Libya \\
\hline 50 & CGN12293 & PI 294478 & T. turgidum & polonicum & $\mathrm{L}$ ? & Spring & 1964 & France \\
\hline 51 & CGN12296 & Biskri $\times$ Bruteille & T. turgidum & durum & B & Spring & 1965 & Morocco \\
\hline 52 & CGN14995 & Sari Bugday & T. turgidum & durum & B & Winter & & Turkey \\
\hline 53 & CGN16051 & & T. turgidum & dicoccon & & Spring & 1964 & France \\
\hline 54 & CGN16057 & Gaza 6; Gaza 277 & T. turgidum & durum & & Spring & 1941 & Egypt \\
\hline 55 & CGN16068 & Saba 22738 & T. turgidum & durum & B & Spring & 1960 & Algeria \\
\hline 56 & CGN16069 & Durum H-2 & T. turgidum & durum & & Spring & 1939 & Egypt \\
\hline 57 & CGN16074 & WTC $1229 / 65$ & T. timopheevi & timopheevi & $\mathrm{L}$ ? & Spring & 1964 & USSR \\
\hline
\end{tabular}

Passport details (CGN, Wageningen, The Netherlands): B is breeder line; L is landrace/traditional cultivar; empty cell means unknown information.

accessions CGN08173, CGN08379, and CGN16074 showed two different phenotypes, but immunoblot protein patterns were the same using both mAbs. Seeds from accession CGN08397 showed four different phenotypes and two different immunoblot protein patterns were detected.

To compare the levels of T-cell stimulatory epitopes present in tetraploid accessions to those in hexaploid wheat varieties, relative intensities were calculated from the obtained immunoblots of the eight tetraploid CGN accessions (Fig. 3). The calculation of relative intensities is our method to measure the amount of epitopes in the different wheat samples and is the method we use to compare the presence and levels of epitopes in wheat, as it takes into account the fact that there are differences in relative expression levels of proteins and that 


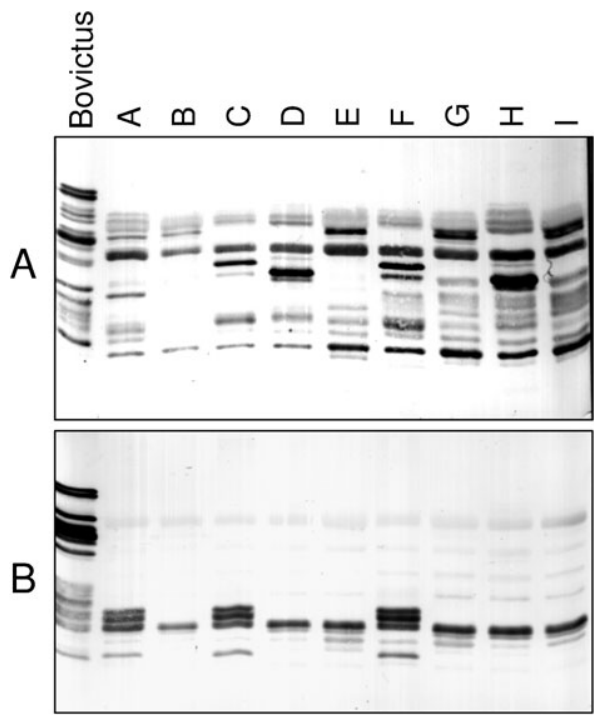

Fig. 2 Immunoblot analysis of gluten protein extracts of nine single seeds (A to I) from accession CGN08006. (A) mAb Glia- $\alpha$ 9, (B) mAb Glia- $\alpha 20$. All gluten proteins reacting to the $\mathrm{mAbs}$ are stained.

some may contain multiple copies of an epitope. Intensities of single seed gluten protein extracts were compared to gluten protein extracts of the modern bread wheat variety Toronto and old bread wheat variety Minaret. Results presented in Fig. 3 showed that when using the mAb against Glia- $\alpha 9$, five of the eight accessions contained lower amounts of T-cell stimulatory epitopes than the hexaploid variety Toronto. Two of these five accessions, CGN08006 and CGN08339, also contained a lower amount of T-cell stimulatory epitopes than the relatively low amount in hexaploid variety Minaret. When using the mAb against Glia- $\alpha 20$, all eight accessions showed more than three-fold reduced amounts of T-cell stimulatory epitopes than the hexaploid variety Toronto. Seven accessions contained lower amounts of T-cell stimulatory epitopes than the hexaploid variety Minaret. The lowest value was obtained for accession CGN08006, which was about two-fold lower than the variety Minaret.

Using the same methods as for the 57 CGN accessions, the 46 tetraploid wheats from INRA (Montpellier) were subsequently analyzed by immunoblotting using mAbs against the same T-cell stimulatory epitopes Glia- $\alpha 9$ and Glia- $\alpha 20$ to identify the number of proteins present containing these epitope sequences. Lines 45963, 117887, 46516, 84866, 95920, and Neodur contained the lowest amount of T-cell stimulatory epitopes and were therefore compared to CGN08006 and CGN08339 and compared to the hexaploid variety Minaret (Fig. 4). Although the gluten protein patterns on the immunoblot are different, these lines overall do not contain less T-cell stimulatory epitopes than the accessions selected from CGN. A calculation of the relative intensities on the immunoblots (Fig. 4) showed that accessions 84866 and Neodur are comparable to accessions CGN08006 and CGN08339 regarding Glia- $\alpha 9$ epitopes. Analysis of the Glia- $\alpha 20$ epitopes showed that Neodur together with CGN08006 are the lowest responders.

\section{Discussion}

In this study we analyzed the genetic diversity and heterogeneity regarding the presence of T-cell stimulatory epitopes of old and modern tetraploid wheat accessions collected from many geographic origins world-wide. The most striking result is that even true tetraploid wheat accessions have a level of CD-epitopes that is not orders of magnitude lower than
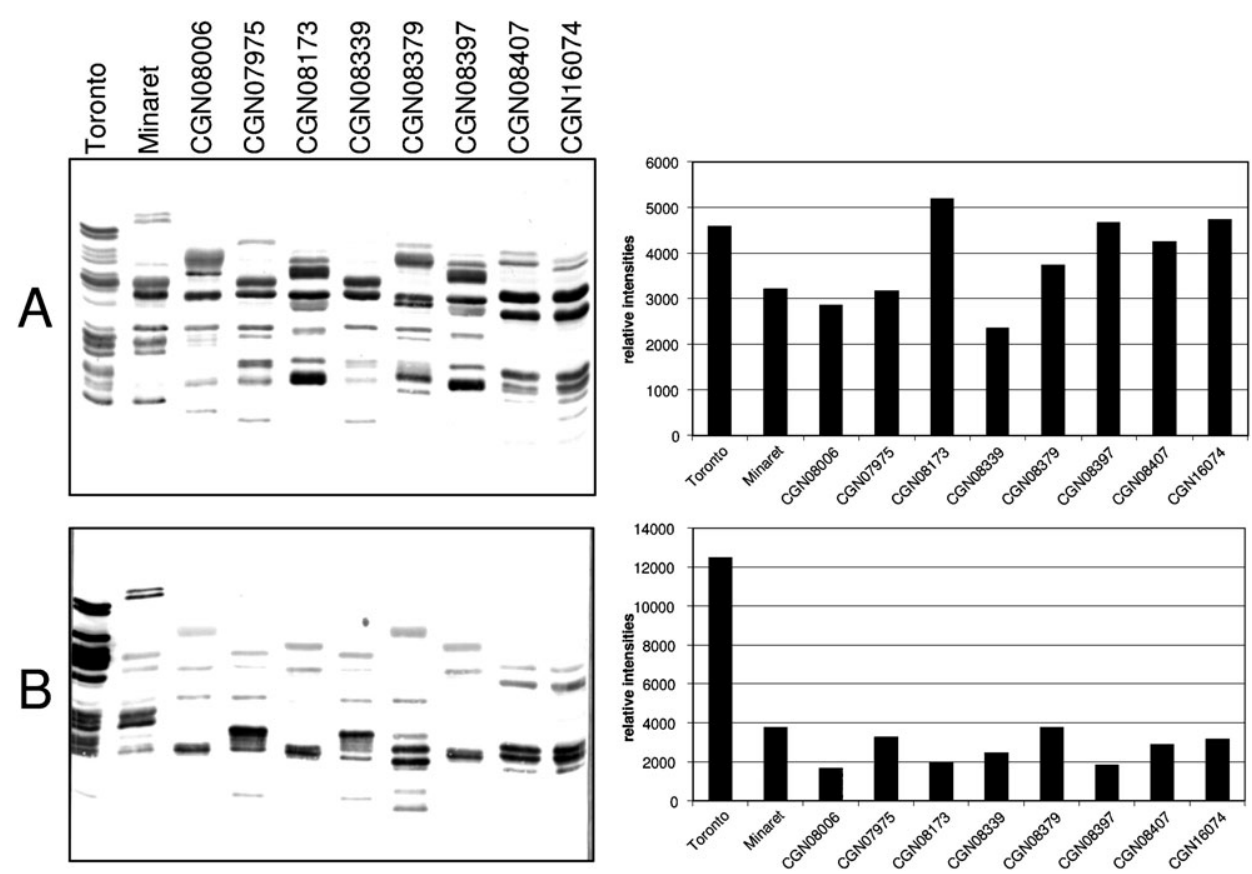

Fig. 3 Immunoblot analysis and calculated intensities of single seed gluten protein extracts from accessions CGN08006, CGN07975, CGN08173, CGN08339, CGN08379, CGN08397, CGN08407, and CGN16074 compared to hexaploid varieties Toronto and Minaret. (A) mAb Glia- $\alpha 9$, (B) $\mathrm{mAb}$ Glia- $\alpha 20$. All gluten proteins reacting to the mAbs are stained on the immunoblots. 


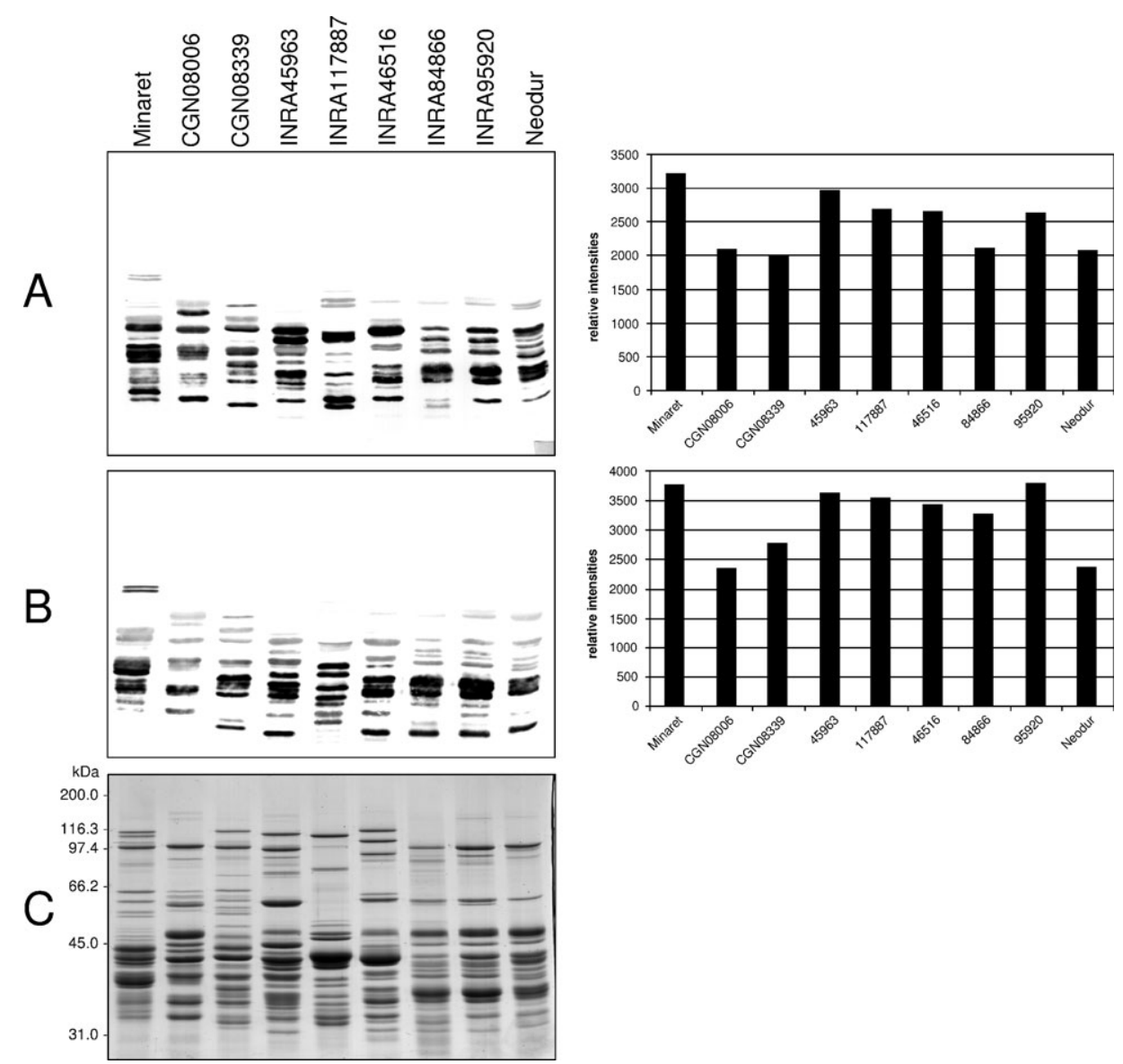

Fig. 4 Immunoblot analysis and calculated intensities of single seed gluten protein extracts from accessions Minaret, CGN08006, CGN08339, INRA45963, INRA117887, INRA46516, INRA84866, INRA95920, and Neodur compared to the hexaploid variety Minaret. (A) mAb Glia- $\alpha$, (B) mAb Glia- $\alpha 20$, (C) SDS-PAGE and PageBlue staining. All gluten proteins reacting to the mAbs are stained on the immunoblots.

observed for hexaploid wheat. This may seem surprising, as the D-genome contains many $\alpha$-gliadins with all epitopes present. ${ }^{19,20}$ On the other hand, the antibodies we used in this study (mAbs against Glia- $\alpha 9$ and Glia- $\alpha 20)$ detect epitopes that are also present in the A-genome $\alpha$-gliadins, which may form the majority of the gliadins being expressed in tetraploid wheat varieties. $^{20}$ There are no antibodies that specifically detect D-genome $\alpha$-gliadin specific epitopes, such as the 33-mer (Salentijn et al. submitted). As a result, the actual differences may be larger than what we detect in this study using immunoblotting with $\mathrm{mAbs}$ against T-cell stimulatory epitopes Glia- $\alpha 9$ and Glia- $\alpha 20$.

Differences among wheat varieties in gluten proteins occur because of allelic variation (genotype) that determines the gluten protein composition. The approach we used in this study analyzes this genotypic variation by comparing the same amount of gluten protein per accession. Changes in gluten protein composition have been described, but are mainly expected if growth conditions are extreme (high or low temperature, dry or wet conditions). ${ }^{28}$ The varieties and accessions we have analyzed were grown under normal wheat growth conditions and therefore, their influence on the gluten protein composition is not expected.

Accessions showing different gluten protein patterns with low CD-epitope content can be selected for making crosses to obtain varieties with different combinations of gluten proteins and reduced numbers of T-cell stimulatory epitopes. To improve dough and baking quality, tetraploid wheats low in T-cell stimulatory epitopes may be highly useful for the construction of synthetic hexaploid bread wheats by hybridization with D-genome species low in T-cell stimulatory epitopes. Baking quality and dough properties of tetraploid wheat can be improved by introduction of or substitution with chromosome $1 \mathrm{D}^{1,29-33}$ or by breeding. In addition, baking quality of tetraploid wheat can also be improved by sexual transfer of the HMW-GS from the D-genome (the Glu-D1 locus) to chromosome $1 \mathrm{~A}$ without adding the gliadins ${ }^{34,35}$ or by genetic transformation using both the $1 D x 5$ and $1 D y 10$ HMW-GS genes. $^{36}$

The occurrence of different genotypes and even different ploidy levels in a single genebank accession is a complicating phenomenon for genebank managers to accurately characterize landraces. Many landraces often result from maintenance and selection practices by local farmers directed towards optimizations to local agronomic and food applications. As a consequence, genebank passport data turned out to be poor predictors of the real genetic composition of landrace accessions that may be mixtures of genotypes of tetraploid and even hexaploid wheat species. Salentijn et al. ${ }^{20}$ analyzed cDNA sequences of $\alpha$-gliadins and observed that some accessions described as 
tetraploid contained Gli-D2 transcripts and in one accession described as hexaploid no Gli-D2 transcript could be found.

It is to be expected that the reduced levels of CD-epitopes, as found among some of the accessions, will not directly result in safe foods to (all) CD-patients. However, we believe that an overall lowering of the 'CD-epitope load' of gluten that is daily consumed by many millions of people world-wide may contribute to delay or even prevent the onset of CD and its symptom development in that part of the population that is genetically susceptible, especially in children ${ }^{37}$ (van den Broeck et al. in press), because the quantity of consumed CD-epitopes is a major factor that may influence the clinical representation of $\mathrm{CD}$, along with some other recognized factors such as the type of cow's milk formulas, omission of breast feeding, and age at gluten introduction. ${ }^{38-41} \mathrm{~A}$ reduction in overall 'CD-epitope load' might especially help to release the constraint of the still undiagnosed CD-patients (approximately 95\% of all CD-patients) who are daily consuming CD-stimulating gluten proteins without realizing its effect on their health and well being. With the present results we show a first and relevant contribution into this direction.

\section{Experimental}

\section{Grain samples}

A set of 57 tetraploid wheats was obtained from the Centre for Genetic Resources (CGN), the Netherlands (http://www.cgn.wur.nl/uk/) (Table 1). The accessions were selected based on collection period and diversity of geographic origin. Some CGN accessions showed heterogeneous seed compositions. In this study, the taxonomy of Triticum of Morris and Sears ${ }^{42}$ is followed. A second set of 46 tetraploid wheat accessions was obtained from INRA (Montpellier) that was selected by genetic diversity based on 10 microsatellites polymorphism and resulted in a core collection as described by David et al. $^{43}$ and Thuillet et al. ${ }^{44}$ (Table 2). Accessions not present at INRA were provided by USDA or ICARDA. Seed compositions of INRA accessions were homogeneous. Both sets included T. turgidum ssp. dicoccoides accessions from the Near East (wild ancestors), domesticated T. turgidum ssp. dicoccon accessions (domesticated ancestors), domesticated T. turgidum ssp. polonicum accessions, old T. turgidum ssp. $\mathrm{d}$ urum varieties, and elite varieties from the French catalog. For comparison, three hexaploid bread wheat varieties (T. aestivum 'Bovictus', 'Toronto', and 'Minaret') have been included.

Accessions CGN06223, CGN08006, and CGN12037 were selected from a previous study on hexaploid wheat accessions (van den Broeck et al. in press). Based on the banding pattern, these accessions seemed to be tetraploids instead of hexaploids. Their tetraploidy was confirmed in flow cytometric ploidy level determination of young leaf material.

\section{Gluten protein extraction}

Multiple $(\sim 10-30)$ wheat grains of 57 tetraploid landraces obtained from CGN, and single grains of selected landraces were ground in an analytical mill (A 11 Basic, IKA-Werke) and sieved through a mesh $(0.5 \mathrm{~mm})$. From 46 tetraploid wheat accessions obtained from INRA (Montpellier) single seeds were used for gluten protein extraction. Gluten proteins were extracted according to van den Broeck et al. (2009) ${ }^{45}$ which describes extraction of most of the gluten proteins. Gluten proteins were extracted from $50 \mathrm{mg}$ wheat flour or ground single seeds by addition of $0.5 \mathrm{ml}$ of $50 \%$ aqueous iso-propanol with continuous mixing (MS1 Minishaker, IKA Works, Inc.) at 1,000 rpm for $30 \mathrm{~min}$ at room temperature, followed by centrifugation at $10,000 \mathrm{rpm}$ for $10 \mathrm{~min}$ at room temperature. The residue was re-extracted twice with $50 \%$ aqueous iso-propanol/1\% DTT/50 mM Tris- $\mathrm{HCl}, \mathrm{pH} 7.5$,

Table 2 Details of tetraploid wheat accessions obtained from INRA-Montpellier, France

\begin{tabular}{|c|c|c|c|c|c|c|c|c|c|}
\hline & Acc nr & Subspecies & Collection site & Type & & Acc nr & Subspecies & Collection site & Type \\
\hline 1 & 45383 & dicoccon & Bulgaria & $\mathrm{D}$ & 24 & 84866 & durum & Syria & $\mathrm{O}$ \\
\hline 2 & 45351 & dicoccon & Iran & $\mathrm{D}$ & 25 & 95920 & durum & Syria & $\mathrm{O}$ \\
\hline 3 & 45239 & dicoccon & Italy & $\mathrm{D}$ & 26 & 82697 & durum & Turkey & $\mathrm{O}$ \\
\hline 4 & 45354 & dicoccon & Russia & $\mathrm{D}$ & 27 & 82726 & durum & Turkey & $\mathrm{O}$ \\
\hline 5 & 45280 & dicoccon & Slovakia & $\mathrm{D}$ & 28 & 82715 & durum & Turkey & $\mathrm{O}$ \\
\hline 6 & 45309 & dicoccon & Slovakia & $\mathrm{D}$ & 29 & Brumaire & durum & France & $\mathrm{O}$ \\
\hline 7 & 352365 & dicoccon & Germany & $\mathrm{D}$ & 30 & Primadur & durum & France & $\mathrm{E}$ \\
\hline 8 & 355484 & dicoccon & Spain & $\mathrm{D}$ & 31 & Neodur & durum & France & $\mathrm{E}$ \\
\hline 9 & 94635 & dicoccon & Iran & $\mathrm{D}$ & 32 & IXOs9442 & durum & France & $\mathrm{E}$ \\
\hline 10 & 415152 & dicoccon & Israel & $\mathrm{D}$ & 33 & Villemur & durum & France & $\mathrm{E}$ \\
\hline 11 & 94648 & dicoccon & Italy & $\mathrm{D}$ & 34 & Armet910 & durum & France & $\mathrm{E}$ \\
\hline 12 & 113302 & dicoccoides & Iran & $\mathrm{W}$ & 35 & Durental & durum & France & $\mathrm{E}$ \\
\hline 13 & 45963 & dicoccoides & Jordan & $\mathrm{W}$ & 36 & Lloyd 945 & durum & France & $\mathrm{E}$ \\
\hline 14 & 46391 & dicoccoides & Jordan & $\mathrm{W}$ & 37 & B6Rtchir & durum & Bulgaria & $\mathrm{O}$ \\
\hline 15 & 117887 & dicoccoides & Syria & $\mathrm{W}$ & 38 & LRB6R595 & durum & Bulgaria & $\mathrm{O}$ \\
\hline 16 & 46470 & dicoccoides & Syria & $\mathrm{W}$ & 39 & 68405 & polonicum & - & D \\
\hline 17 & 46253 & dicoccoides & Turkey & $\mathrm{W}$ & 40 & 585015 & polonicum & China & D \\
\hline 18 & 116172 & dicoccoides & Turkey & $\mathrm{W}$ & 41 & 384266 & polonicum & Ethiopia & $\mathrm{D}$ \\
\hline 19 & 467014 & dicoccoides & Israel & $\mathrm{W}$ & 42 & 14140 & polonicum & - & $\mathrm{D}$ \\
\hline 20 & 428133 & dicoccoides & Lebanon & $\mathrm{W}$ & 43 & 81285 & turgidum & - & $\mathrm{D}$ \\
\hline 21 & 46516 & dicoccoides & Syria & $\mathrm{W}$ & 44 & 7786 & turgidum & Ethiopia & $\mathrm{D}$ \\
\hline 22 & 487255 & dicoccoides & Syria & $\mathrm{W}$ & 45 & 387456 & turgidum & Ethiopia & $\mathrm{D}$ \\
\hline 23 & Kubanka & durum & USSR & $\mathrm{O}$ & 46 & 134952 & turgidum & Portugal & $\mathrm{D}$ \\
\hline
\end{tabular}


for $30 \mathrm{~min}$ at $60{ }^{\circ} \mathrm{C}$ with mixing every 5 to $10 \mathrm{~min}$ followed by centrifugation at $10,000 \mathrm{rpm}$ for $10 \mathrm{~min}$ at room temperature. After addition of each next extraction solution, the residue was resuspended by shaking in a Fastprep ${ }^{\circledR}$ FP220A Instrument for $10 \mathrm{~s}$ at a speed of $6.5 \mathrm{~m} \mathrm{~s}^{-1}$ followed by sonification for 10 min in an ultrasonic bath (Branson 3510, Branson Ultrasonics Corporation). The three obtained supernatants were combined and considered as the total gluten protein extract. The protein content was quantified using Bio-Rad Protein Assay (Bio-Rad Laboratories), based on the Bradford dye-binding procedure, according to the manufacturer's instruction.

\section{SDS-PAGE and immunoblotting}

Equal amounts of gluten proteins were separated on SDS-PAGE gels $(10 \%)^{46}$ using a Hoefer SE 260 mighty small II system (GE Healthcare) followed by staining with PageBlue ${ }^{\mathrm{TM}}$ (Fermentas). Proteins were blotted onto nitrocellulose $(0.2 \mu \mathrm{m}$, Bio-Rad Laboratories), omitting methanol from the blotting buffer, using a Mini Trans-Blot Cell (Bio-Rad Laboratories) at $100 \mathrm{~V}$ for $1 \mathrm{~h}$. Blots were stained using a MemCode $^{\mathrm{TM}}$ Reversible Protein Stain Kit for Nitrocellulose Membranes (Fisher Scientific) prior to incubation with mAbs. Incubation with $\mathrm{mAbs}$ specific for T-cell stimulatory epitopes Glia- $\alpha 9^{47,48}$ and Glia- $\alpha 20^{47,49}$ was performed as described. ${ }^{50}$ Antibody binding to the blots was visualized by staining for alkaline phosphatase conjugated secondary antibody, using Nitro Blue tetrazolium (NBT) and 5-bromo-4-chloro-3-indolyl phosphate (BCIP) (Sigma). Blots were scanned using a Bio-Rad GS-710 Calibrated Imaging Densitometer (Bio-Rad Laboratories) and saved as TIFF images. Pixel intensities were calculated per lane using Quantity One software (Bio-Rad Laboratories). The gluten protein extracts of either the modern hexaploid wheat varieties Bovictus or Toronto (having high amounts of T-cell stimulatory epitopes, as analyzed before) and/or the hexaploid wheat variety Minaret (with relatively low amounts of T-cell stimulatory epitopes) were used on each separate immunoblot as an 'inter-gel' control as in van den Broeck et al. (in press).

\section{Acknowledgements}

The authors would like to acknowledge Noor Bas at the Centre for Genetic Resources, The Netherlands (CGN), for selecting the tetraploid wheat accessions and Simon Ribot for grinding these tetraploid wheat accessions. Many thanks to Prof. dr. Frits Koning and Dr Liesbeth Dekking from Leiden University Medical Centre, The Netherlands, for providing us with the mAbs. Prof. dr. Chen Hongbing from Nanchang University in China was funded by the China Scholarship Council. This research was funded by the Celiac Disease Consortium, an Innovative Cluster approved by the Netherlands Genomics Initiative, and partially funded by the Dutch Government (BSIK03009), and by the Ministry of Agriculture, Nature, and Food Quality of The Netherlands through the DLO program 'Plant and Animal for Human Health' (project KB-05-001-019-PRI).

\section{References}

1 D. Lafiandra, C. Ceoloni, R. Carozza, B. Margiotta, M. Urbano, G. Colaprico and M. D'Egidio, Wheat Production in Stressed Environments, ed. H. T. Buck, J. E. Nisi and N. Salomón, Springer, Netherlands, 2007, pp. 449-454.

2 B. L. Johnson and H. S. Dhaliwal, Am. J. Bot., 1976, 63, $1088-1094$.

3 S. Huang, A. Sirikhachornkit, X. Su, J. Faris, B. Gill, R. Haselkorn and P. Gornicki, Proc. Natl. Acad. Sci. U. S. A., 2002, 99, 8133-8138.

4 N. Chantret, J. Salse, F. Sabot, S. Rahman, A. Bellec, B. Laubin, I. Dubois, C. Dossat, P. Sourdille, P. Joudrier, M.-F. Gautier, L. Cattolico, M. Beckert, S. Aubourg, J. Weissenbach, M. Caboche, M. Bernard, P. Leroy and B. Chalhoub, Plant Cell, 2005, 17, 1033-1045.

5 J. Dvorak, P. Di Terlizzi, H. B. Zhang and P. Resta, Genome, 1993, 36, 21-31.

6 H. Ozkan, A. Brandolini, R. Schafer-Pregl and F. Salamini, Mol. Biol. Evol., 2002, 19, 1797-1801.

7 T. A. Brown, M. K. Jones, W. Powell and R. G. Allaby, Trends Ecol. Evol., 2009, 24, 103-109.

8 J. Dubcovsky and J. Dvorak, Science, 2007, 316, 1862-1866.

9 M. Heun, R. Schafer-Pregl, D. Klawan, R. Castagna, M. Accerbi, B. Borghi and F. Salamini, Science, 1997, 278, 1312-1314.

10 M. Nesbitt and D. Samuel, Science, 1998, 279, 1433.

11 A. C. Zeven, Euphytica, 2000, 116, 65-85.

12 P. R. Shewry and A. S. Tatham, Biochem. J., 1990, 267, 1-12.

13 G. Branlard, M. Dardevet, R. Saccomano, F. Lagoutte and J. Gourdon, Euphytica, 2001, 119, 59-67.

14 P. I. Payne, Annu. Rev. Plant Physiol., 1987, 38, 141-153.

15 L. M. Sollid, Nat. Rev. Immunol., 2002, 2, 647-655.

16 S. Lohi, K. Mustalahti, K. Kaukinen, K. Laurila, P. Collin, H. Rissanen, O. Lohi, E. Bravi, M. Gasparin, A. Reunanen and M. Mäki, Aliment. Pharmacol. Ther., 2007, 26, 1217-1225.

17 A. Rubio-Tapia, R. A. Kyle, E. L. Kaplan, D. R. Johnson, W. Page, F. Erdtmann, T. L. Brantner, W. R. Kim, T. K. Phelps, B. D. Lahr, A. R. Zinsmeister, L. J. Melton III and J. A. Murray, Gastroenterology, 2009, 137, 88-93.

18 J. Atchison, L. Head and A. Gates, Geoforum, 2010, 41, 236-246.

19 T. W. J. M. van Herpen, S. Goryunova, J. van der Schoot, M. Mitreva, E. M. J. Salentijn, O. Vorst, M. Schenk, P. van Veelen, F. Koning, L. van Soest, B. Vosman, D. Bosch, R. J. Hamer, L. J. W. J. Gilissen and M. J. M. Smulders, BMC Genomics, 2006, 7, 1.

20 E. M. J. Salentijn, S. Goryunova, N. Bas, I. M. van der Meer, H. C. van den Broeck, T. Bastien, L. J. W. J. Gilissen and M. J. M. Smulders, BMC Genomics, 2009, 10, 48.

21 L. Shan, Ø. Molberg, I. Parrot, F. Hausch, F. Filiz, G. M. Gray, L. M. Sollid and C. Khosla, Science, 2002, 297, 2275-2279.

22 L. Shan, S. W. Qiao, H. Arentz-Hansen, Ø. Molberg, G. M. Gray, L. M. Sollid and C. Khosla, J. Proteome Res., 2005, 4, $1732-1741$.

23 S. Auricchio, G. De Ritis and M. De Vincenzi, Pediatr. Res., 1982, 16, 1004-1010.

24 Ø. Molberg, A. K. Uhlen, T. Jensen, N. S. Flæte, B. Fleckenstein, H. Arentz-Hansen, M. Raki, K. E. A. Lundin and L. M. Sollid, Gastroenterology, 2005, 128, 393-401.

25 L. Spaenij-Dekking, Y. Kooy-Winkelaar, P. van Veelen, J. W. Drijfhout, H. Jonker, L. van Soest, M. J. M. Smulders, D. Bosch, L. J. W. J. Gilissen and F. Koning, Gastroenterology, 2005, 129, 797-806.

26 A. Konic-Ristic, D. Dodig, R. Krstic, S. Jelic, I. Stankovic, A. Ninkovic, J. Radic, I. Besu, B. Bonaci-Nikolic, N. Jojic, M. Djordjevic, D. Popovic and Z. Juranic, BMC Immunol., 2009, 10, 32 .

27 H. C. van den Broeck, T. J. W. M. van Herpen, C. Schuit, E. M. J. Salentijn, L. Dekking, D. Bosch, R. J. Hamer, M. J. M. Smulders, L. J. W. J. Gilissen and I. M. van der Meer, BMC Plant Biol., 2009, 9, 41.

28 D. M. R. Georget, C. Underwood-Toscano, S. J. Powers, P. R. Shewry and P. S. Belton, J. Agric. Food Chem., 2008, 56, $1172-1179$.

29 C. Ceoloni, M. Biagetti, M. Ciaffi, P. Forte and M. Pasquini, Euphytica, 1996, 89, 87-97. 
30 C. Ceoloni, P. Forte, A. Gennaro, S. Micali, R. Carozza and A. Bitti, Cytogenet. Genome Res., 2005, 109, 328-334.

31 A. J. Lukaszewski and C. A. Curtis, Plant Breed., 1994, 112, 177-182.

32 F. Vitellozzi, M. Ciaffi, L. Dominici and C. Ceoloni, Agronomie, 1997, 17, 413-419.

33 G. Y. He, L. Rooke, S. Steele, F. Békés, P. Gras, A. S. Tatham, R. Fido, P. Barcelo, P. R. Shewry and P. A. Lazzeri, Mol. Breed., 1999, 5, 377-386.

34 J. Dumur, J. Jahier, M. Dardevet, H. Chiron, A. M. Tanguy and G. Branlard, J. Cereal Sci., 2010, 51, 175-181.

35 J. Dumur, G. Branlard, A. M. Tanguy, M. Dardevet, O. Coriton, V. Huteau, J. Lemoine and J. Jahier, Theor. Appl. Genet., 2009, 119, 471-481.

36 A. Gadaleta, A. Blechl, S. Nguyen, M. Cardone, M. Ventura, J. Quick and A. Blanco, Mol. Breed., 2008, 22, 267-279.

37 M. Silano, C. Agostoni and S. Guandalini, World J. Gastroenterol., 2010, 16, 1939-1942.

38 A. Fasano and C. Catassi, Gastroenterology, 2001, 120, 636-651.

39 G. J. Tack, W. H. M. Verbeek, M. W. J. Schreurs and C. J. J. Mulder, Nat. Rev. Gastroenterol. Hepatol., 2010, 7, 204-213.

40 M. A. Selimoglu and H. Karabiber, J. Clin. Gastroenterol., 2010, 44, 4-8.
41 E. K. George, M. L. Mearin, H. C. Franken, R. H. Houwen, R. A. Hirasing and J. P. Vandenbroucke, Gut, 1997, 40, 61-66.

42 R. Morris and E. R. Sears, in Wheat and Wheat Improvement, ed. R. S. Quisenberry and L. P. Reitz, American Society of Agronomy, Madison WI, 1967, pp. 19-85.

43 J. L. David, T. Bataillon, S. Poirier and A.-C. Thuillet, 10th International Wheat Genetics Symposium, Paestum, Italy, 2003.

44 A.-C. Thuillet, T. Bataillon, S. Poirier, S. Santoni and J. L. David, Genetics, 2005, 169, 1589-1599.

45 H. C. van den Broeck, A. H. P. America, M. J. M. Smulders, D. Bosch, R. J. Hamer, L. J. W. J. Gilissen and I. M. van der Meer, J. Chromatogr., B: Biomed. Appl., 2009, 877, 975-982.

46 U. K. Laemmli, Nature, 1970, 227, 680-685.

47 C. Mitea, Y. Kooy-Winkelaar, P. van Veelen, A. de Ru, J. W. Drijfhout, F. Koning and L. Dekking, Am. J. Clin. Nutr., 2008, 88, 1057-1066.

48 E. H. A. Spaenij-Dekking, E. M. C. Kooy-Winkelaar, W. F. Nieuwenhuizen, J. W. Drijfhout and F. Koning, Gut, 2004, 53, 1267-1273.

49 C. Mitea, R. Havenaar, J. W. Drijfhout, L. Edens, L. Dekking and F. Koning, Gut, 2008, 57, 25-32.

50 J. H. G. Cordewener, G. Hause, E. Görgen, R. Busink, B. Hause, H. J. M. Dons, A. A. M. van Lammeren, M. M. van Lookeren Campagne and P. Pechan, Planta, 1995, 196, 747-755. 